\title{
Numerical Investigation of Gob-Side Entry Retaining through Precut Overhanging Hard Roof to Control Rockburst
}

\author{
Xiaoming Sun $\left(\mathbb{D},{ }^{1}\right.$ Li Gan $\left(\mathbb{D},{ }^{1,2}\right.$ Zhao Chengwei, ${ }^{1,2}$ Tang Jianquan, ${ }^{3}$ He Manchao, ${ }^{1}$ \\ Song Peng, ${ }^{1}$ and Miao Chengyu, ${ }^{1,2}$ \\ ${ }^{1}$ State Key Laboratory for Geomechanics and Deep Underground Engineering, Beijing 100083, China \\ ${ }^{2}$ School of Mechanics and Civil Engineering, China University of Mining and Technology, Beijing 100083, China \\ ${ }^{3}$ Shandong University of Science and Technology, Taian 271000, China \\ Correspondence should be addressed to Xiaoming Sun; sxmcumtb@163.com and Li Gan; 303521087@qq.com
}

Received 29 March 2018; Revised 4 October 2018; Accepted 31 October 2018; Published 6 December 2018

Guest Editor: Qianbing Zhang

Copyright $(92018$ Xiaoming Sun et al. This is an open access article distributed under the Creative Commons Attribution License, which permits unrestricted use, distribution, and reproduction in any medium, provided the original work is properly cited.

Gob-side entry retaining through precut overhanging hard roof (GERPOHR) method is one of the commonly used methods for nonpillar mining. However, feasibility studies of controlling rockburst by this method are few. Rockburst occurs in hard thick strata with a higher probability, larger scale, and higher risk. To better understand the GERPOHR method is beneficial for rockburst mitigation. In this paper, the design of GERPOHR was first introduced. And the layout of the working face was optimized. Then, based on the numerical simulation, the stress and displacement distribution characteristics were compared under the condition of conventional mining and GERPOHR method. The research shows that the intervals of main roof weighting could be decreased through the precut overhanging hard roof method. And the peak value of abutment pressure decreased. Meanwhile, the energy accumulation and the stress fluctuation could be alleviated in roadway surrounding rock.

\section{Introduction}

Rockburst is one of the major disasters in underground mining, especially under hard thick strata. The key reason is elastic strain energy that accumulates in overhanging hard roof and coal pillar [1-3]. Based on incomplete statistics in China, rockburst disaster had happened 107 times in 1998-2014 (more than 30 people died) in Yima coal mine. The rockburst accident of Shandong Chaoyang Coal Mine led five people to death in November 17, 2012. Since March 8, 1992, Huafeng Coal Mine rockburst has occurred more than 100 times, which has caused many casualties. And rockburst accidents have also occurred many times in Xing'an Coal Mine and Junde Coal Mine. The common characteristics of these accidents are the coal seam with hard and thick immediate roof

In recent years, many experts and scholars have conducted considerable research investigating the mechanism, monitoring, predicting, and controlling rockburst $[2,4-6]$. The safe and reliable control measures are important for rockburst. Thus, it still needs further study. The main controlling strategies of rockburst are to change the stress state and the pattern of energy release. The common method includes mine layout and pillar design $[7,8]$, deep blasting relieving pressure technology [9], water infusion [10], stress relief boreholes [4], rock support [11], hard rock roof fracturing method [12], etc.

Controlling the rockburst caused by overhanging hard roof, the hard rock roof fracturing and no-pillar mining are efficient and robust methods. Hu et al. [12] proposed that the directional hydraulic fracturing method (deep-hole directional fracturing of thick hard roof) was an effective measure to control rockburst, by means of number simulation, drilling bits, and microseismic system. The long-hole drilling and the blasting methods were used to precrack hard roof so that the panel was smoothly extracted without any further rockburst [13]. There has been a large amount of research on explaining the mechanical mechanisms of rock bursting induced by a coal pillar and analyzing the pressure relief method to control rockburst $[14,15]$. 
Gob-side entry retaining technology by overlying strata cutting was used as an effective method to decrease the pressure of roadway [16]. However, current research was insufficient on the control mechanism of rockburst by gobside entry retaining technology. Therefore, this paper introduced the GERPOHR technology and the control mechanism of rockburst. And based on numerical simulation theory, the comparative analysis between the conventional and GERPOHR mining method was investigated. The contrast indexes include overhanging hard roof movement pattern, stress distribution, and roadways roof stability.

This study can provide guidance for understanding the influences of precut overhanging hard roof technology to control rockburst.

\section{Rockburst Mitigation Mechanism of Gob- Side Entry Retaining through Precut Overhanging Hard Roof Method}

Nonpillar mining method of gob-side entry retaining by roof cutting is emerging and developing in China [17-19] However, there are few studies on controlling rockburst using this method. In this paper, based on the GERPOHR method, the layout of the working face was improved and the hard roof method with the precut roof was adopted on both sides of the working face.

The GERPOHR method is shown in Figure 1. Firstly, the roadway was strengthened to keep the roadway stable in the roof cutting process. The reinforcement measures commonly used have advance support and add constant resistance anchorage cable [20]. Then, the presplitting blasting was conducted inside the roadway to fracture the overlying thick rock. The overlying roof will fall under mine pressure. Eventually, a roadway with solid coal on the one side and gangue goaf on the other side was created. The process would be repeated, and finally coal pillar would be nonexistent in the mining area.

The propagation path of stress in hard and thick strata will be cut off, and the roadway will be in the low stress region. Based on this technique, the elastic energy greatly decreased from coal pillar and load transfer of the roof from goaf. And the roof boundary condition with four edges fixed turns into opposite boundary completely clamped support and others free boundary condition. Therefore, the first weighting interval of hard roof will decrease, and the bending elastic energy of the roof will decrease.

\section{Numerical Simulation Establishment}

Based on the analysis result, the GERPOHR method can decrease roadway surrounding rock stress and the effect of overlying hard roof. Based on the numerical simulation method, this research focuses on comparing with the traditional technology about the roof weighting step, stress distribution characteristics, and roadway roof stability. The simulation was based on the same geological condition.
3.1. Engineering Geology Situation. Junde Coal Mine 9103 working face is located in the region of No. 17 mining area, and the inclination is from $27^{\circ}$ to $32^{\circ}$. The average thickness of coal seam is $12 \mathrm{~m}$. The average depth of coal mining is $500 \mathrm{~m}$. The coal seam is overlain successively by siltstone $(7 \mathrm{~m})$, fine sandstone $(41 \mathrm{~m})$, grit stone $(25 \mathrm{~m})$, fine sandstone $(40 \mathrm{~m})$, siltstone $(2 \mathrm{~m})$, and coal seam $15(0.9 \mathrm{~m})$ and underlain successively by tuff $(4.9 \mathrm{~m})$ and fine sandstone $(25.8 \mathrm{~m})$, as shown in Figure 2. Fully mechanized slice mining is adopted in Junde Coal Mine 9103 working face, with the mining height of $3.5 \mathrm{~m}$. The designed face is $1000 \mathrm{~m}$ in length and $150 \mathrm{~m}$ in width. The roadway was reinforced by "double deck steel mesh + steel anchor + anchor," with $5.6 \mathrm{~m} \times 3.5 \mathrm{~m}\left(20 \mathrm{~m}^{2}\right)$ section. Five accidents of rockburst have occurred in the 9103 working face.

Based on the GB/T 25217.2-2010 about rockburst tendency classification, the comprehensive judgement of hard roof indicates the rock with strong rockburst tendency. The formula was shown for calculating the bending energy index of single roof. The result of roof rockburst tendency is shown in Table 1:

$$
U_{\mathrm{WQ}}=102.6 \frac{\left(R_{\mathrm{t}}\right)^{(5 / 2)} h^{2}}{q^{(1 / 2)} E}
$$

where $U_{\mathrm{WQ}}$ is single roof bending energy index $(\mathrm{kJ}) ; R_{\mathrm{t}}$ is tensile strength of rock (MPa); $h$ is roof thickness (m); and $E$ is elastic modulus (MPa).

Based on the in situ stress result of No. 17 coal seam in Junde Coal Mine, the maximum principal stress is about $23 \mathrm{MPa}$ on horizontal principal stress. The direction is northward, and it is nearly parallel to the mining roadway. The direction of minimum horizontal stress is east, $13 \mathrm{MPa}$. The vertical principal stress is $16.3 \mathrm{MPa}$.

3.2. Numerical Simulation Model. This paper adopts 3DEC dynamic module. The 3DEC numerical simulation software is a discrete element algorithm program. The software can truly demonstrate the nonlinear deformation state of strata movement caused by coal seam excavation. Rock blocks interact with each other through structural planes. When the structural planes exceed the bearing capacity, the shear dislocation or tensile disengagement will produce in rock blocks. Dynamic analysis is required for mining problems involving seismic release of energy (i.e., rockburst) and flow of particles (angular or rounded) under gravity. The auto damping method was applied in this paper, which is proposed by Professor Cundall [21]. The damping increased when the energy ratio is less than 0.5 , and the damping decreased when the energy ratio is greater than 0.5 . The energy ratio can be calculated as follows:

$$
R=\sum\left(E_{\mathrm{D}} / \dot{E}_{\mathrm{K}}\right)
$$

where $R$ is the energy ratio; $E_{\mathrm{D}}$ is the energy is absorbed by damping; and $\dot{E}_{\mathrm{K}}$ is system energy gradient. 


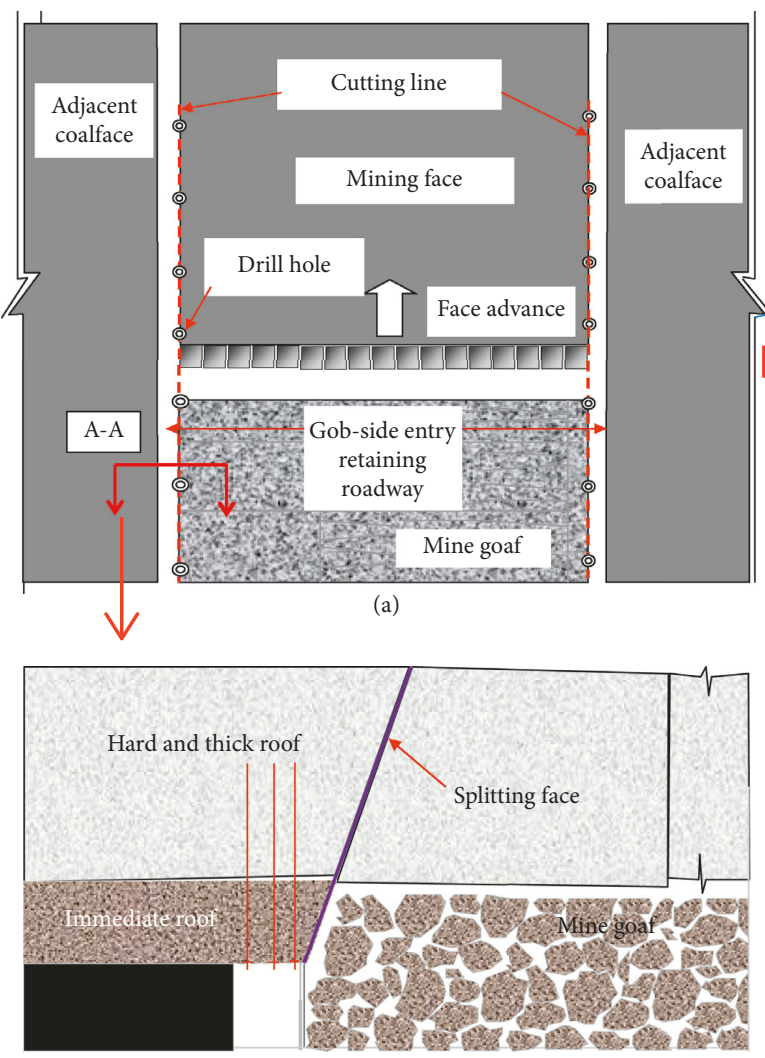

(b)

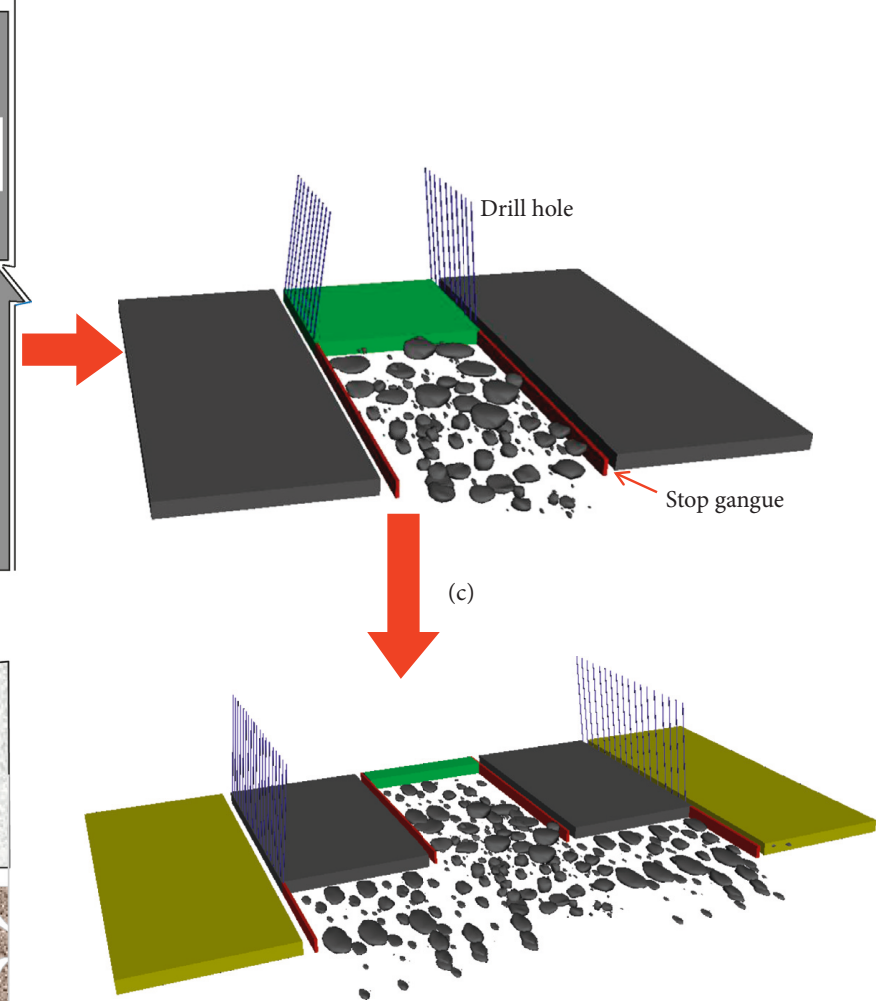

(d)

FIgURE 1: Schematic diagram of GERPOHR technology. (a) Technical schematic diagram. (b) Profile design. (c) Three-dimensional view. (d) Layout of the working face.

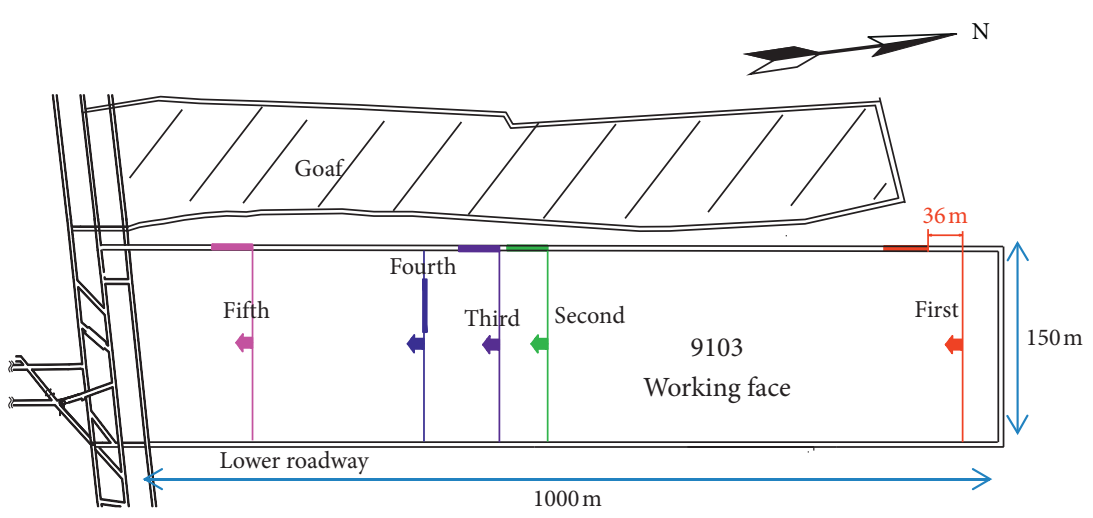

(a)

\begin{tabular}{|c|c|c|c|}
\hline Rock type & Legend & $\begin{array}{l}\text { Thickness } \\
\text { (m) }\end{array}$ & $\begin{array}{c}\text { Gross } \\
\text { thickness (m) }\end{array}$ \\
\hline Coal seam 15 & & 0.9 & 411.8 \\
\hline Silty sandstone & & 2.0 & 412.7 \\
\hline Fine sandstone & & 30 & 414.7 \\
\hline Grit stone & & 25 & 444.7 \\
\hline Fine sandstone & & 41 & 469.7 \\
\hline Silty sandstone & & 7 & 510.7 \\
\hline Coal seam 17 & & 12 & 517.7 \\
\hline Tuff & & 4.9 & 529.7 \\
\hline Fine sandstone & d. & 25.8 & 534.6 \\
\hline
\end{tabular}

(b)

Figure 2: Geological and mining condition of selected panel.

TABLE 1: Determination of rockburst tendency.

\begin{tabular}{lccccc}
\hline $\begin{array}{l}\text { Tensile strength } \\
(\mathrm{MPa})\end{array}$ & $\begin{array}{c}\text { Roof thickness } \\
(\mathrm{m})\end{array}$ & $\begin{array}{c}\text { Rock elastic modulus } \\
(\mathrm{GPa})\end{array}$ & $\begin{array}{c}\text { Overburden load } \\
(\mathrm{MPa})\end{array}$ & $\begin{array}{c}\text { Single roof bending energy } \\
\text { index }(\mathrm{kJ})\end{array}$ & $\begin{array}{c}\text { Rockburst tendency } \\
\text { result }\end{array}$ \\
\hline 13.88 & 41 & 95.5 & 0.0378 & 6342 & Strong \\
\hline
\end{tabular}


TABLE 2: Strata material properties.

\begin{tabular}{|c|c|c|c|c|c|c|c|c|}
\hline Location & Lithology & $\begin{array}{c}\text { Thickness } \\
\text { (m) }\end{array}$ & $\begin{array}{c}\text { Bulk } \\
\text { modulus } \\
(\mathrm{GPa})\end{array}$ & $\begin{array}{c}\text { Shear } \\
\text { modulus } \\
(\mathrm{GPa})\end{array}$ & $\begin{array}{l}\text { Density } \\
\left(\mathrm{kg} / \mathrm{m}^{3}\right)\end{array}$ & $\begin{array}{c}\text { Frictional } \\
\text { angle } \\
\text { (ri) }\end{array}$ & $\begin{array}{c}\text { Cohesion } \\
(\mathrm{MPa})\end{array}$ & $\begin{array}{c}\text { Tensile } \\
\text { strength } \\
(\mathrm{MPa})\end{array}$ \\
\hline Roof & Siltstone & 2 & 8.1 & 3.3 & 2500 & 27.9 & 16 & 7.6 \\
\hline Roof & $\begin{array}{c}\text { Fine } \\
\text { sandstone }\end{array}$ & 30 & 10.3 & 6.3 & 2600 & 32.7 & 14.6 & 10.2 \\
\hline Roof & Grit stone & 25 & 9 & 3.5 & 2340 & 31 & 12 & 5.9 \\
\hline Main roof & $\begin{array}{c}\text { Fine } \\
\text { sandstone }\end{array}$ & 41 & 10.2 & 4.7 & 2500 & 32 & 9.8 & 6.5 \\
\hline Roof & Siltstone & 7 & 8.1 & 3.3 & 2500 & 27.9 & 16 & 7.6 \\
\hline Coal seam & Coal & 12 & 3.5 & 1.6 & 1340 & 31 & 1.4 & 1.6 \\
\hline $\begin{array}{l}\text { Immediate } \\
\text { floor }\end{array}$ & Tuff & 4.9 & 9.5 & 5.8 & 2500 & 31.2 & 13.5 & 9.7 \\
\hline Floor & $\begin{array}{c}\text { Fine } \\
\text { sandstone }\end{array}$ & 25.8 & 10.3 & 6.3 & 2600 & 32.7 & 14.6 & 10.2 \\
\hline
\end{tabular}

In order to absorb the reflection of stress wave, viscous boundary was used in the numerical model. The physical and mechanical properties of intact rock used in the model are given in Table 2. The models of intact rock and joint rock were the Mohr-Coulomb model and the Coulomb slip model, respectively.

The numerical model is a cuboid of dimensions $410 \mathrm{~m} \times$ $200 \mathrm{~m} \times 300 \mathrm{~m}$ with gravity acting along the negative $z$ axis. The inclination of working face is $27^{\circ}$, as shown in Figure 3(a). Figure 3(b) is the numerical calculation model under conventional mining condition. Figure $3(\mathrm{c})$ is the GERPOHR model. Figure 3(d) shows the location of monitoring point for roadway roof stress and displacement.

\section{Analysis of Simulation Results}

4.1. Evolution Characteristic of Vertical Displacement in Key Strata. In order to study the fracture characteristic of overhanging hard roof (key strata) under the different mining methods, the vertical displacement of key stratum was analyzed on the upper working face $150 \mathrm{~m}$. The $\mathrm{z}$-displacement curve of key strata is shown in Figure 4. Before the strata movement, the coordinates of all nodes on the middle line of the hard thick rock stratum were obtained. The numerical software uses the Lagrange solution model. Therefore, the final coordinates of the above nodes can be obtained after the stratum movement. The difference between node coordinates is the distance of strata movement. The maximum vertical displacement of key strata is $3.3 \mathrm{~m}$. It showed that the fracture interval of key strata is $150 \mathrm{~m}$ under the conventional mining condition. The GERPOHR method contributed to decrease the fracture interval, the first weighting step $110 \mathrm{~m}$.

Figures 5(a)-5(b) show the movement of overlying strata and the distribution of plastic zones under the GERPOHR condition. It shows that the rock stratum is asymmetric deformation under the effect of dip angle. In the second working face, the roadway is in the reduced pressure zone, which can effectively alleviate energy accumulation. It plays an important role in controlling rockburst. Figures 5(c)-5(d) show the movement of overlying strata and the distribution of plastic zones under the conventional mining condition. In the second working face, the roadway is in the pressure unrelieved zone.

4.2. The Distribution of Surrounding Rock Stress during Two Mining Methods. The vertical stress will redistribute in the effect of mining disturbance. It may cause stress concentration near roadway and working face. Stress concentration increases the risk of rockburst occurrence. The rock stratum below $0.5 \mathrm{~m}$ of coal seam was selected as data extraction plane. The distribution of vertical abutment pressure was obtained under the condition of conventional mining and GERPOHR method, as shown in Figure 6. Figures 6(a)-6(b) show that the stress concentration zone is located ahead of the coalfaces, surrounding roadways and coal pillar. In the mining process of second working face, the roadway was affected by the stress concentration on the entity coal and the coal pillar. The GERPOHR method can eliminate the stress concentration of coal pillars and decrease advance support pressure of working face, as shown in Figures 6(c)-6(d).

In order to better analyze the influence of two mining methods on roadway stability, the positions of the measuring lines were selected at advanced abutment stress area in the $X$-direction. Figure 7 (a) demonstrates that stress concentration occurs on both sides of the roadway during upper working face mining. The peak value of abutment pressures is $25.1 \mathrm{MPa}$ and $22.8 \mathrm{MPa}$, respectively, in conventional mining and precut overhanging hard roof mining condition. Because of the GERPOHR method, the gob-side entry retaining roadway is in the plastic zone. The surrounding rock of roadway would not accumulate more stress. When mining at the second working face, precut overhanging hard roof mining can reduce abutment pressure, as shown in Figures 7(b)-7(c).

4.3. Dynamic Evolution Process of Roadway Roof Stress. Figure 8 illustrates the movement pattern of roof under two different mining conditions. Under conventional mining condition, the hard and thick roof will gather a lot 


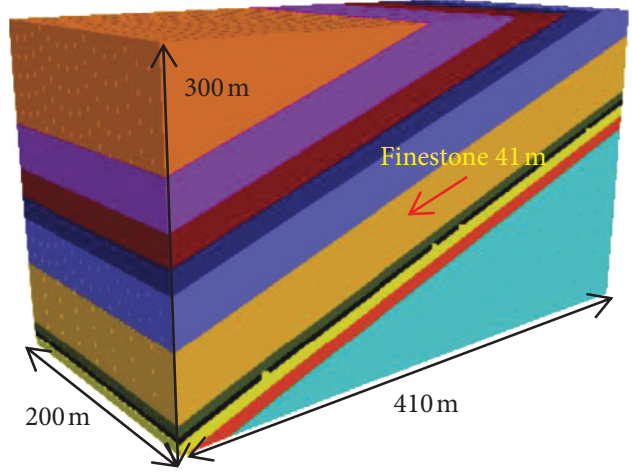

(a)

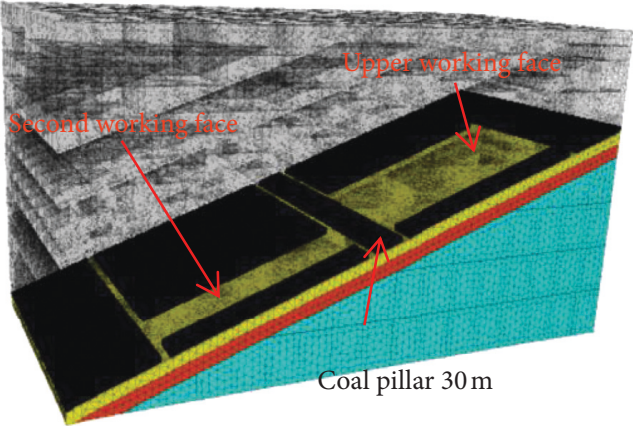

(b)

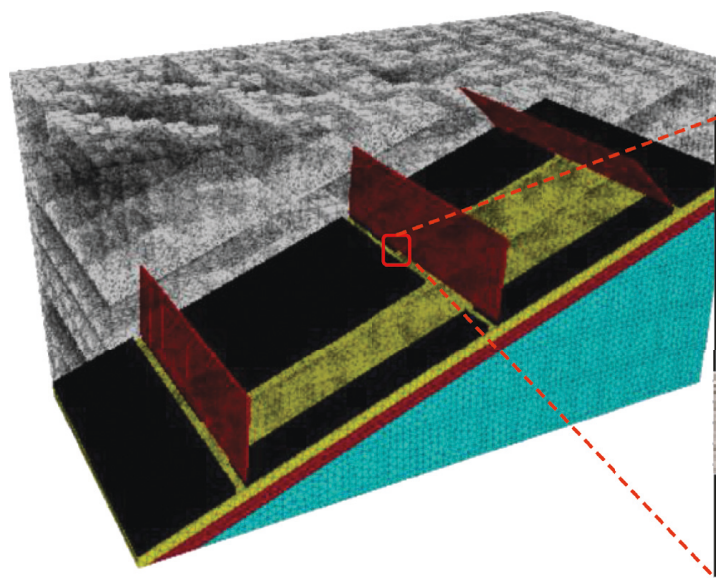

(c)

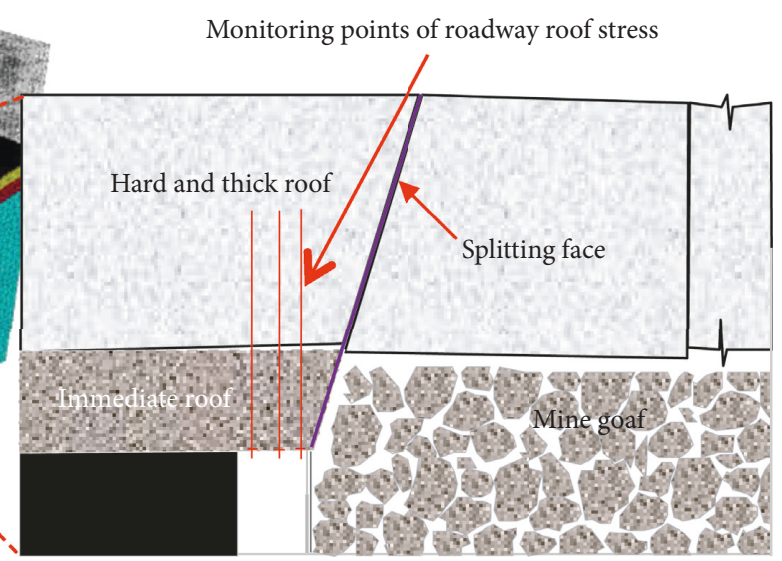

(d)

FIGURE 3: Numerical model, model dimensions, and monitoring points. (a) Numerical simulation model. (b) Conventional mining model. (c) Precut overhanging hard roof model. (d) Monitoring points for roadway roof.

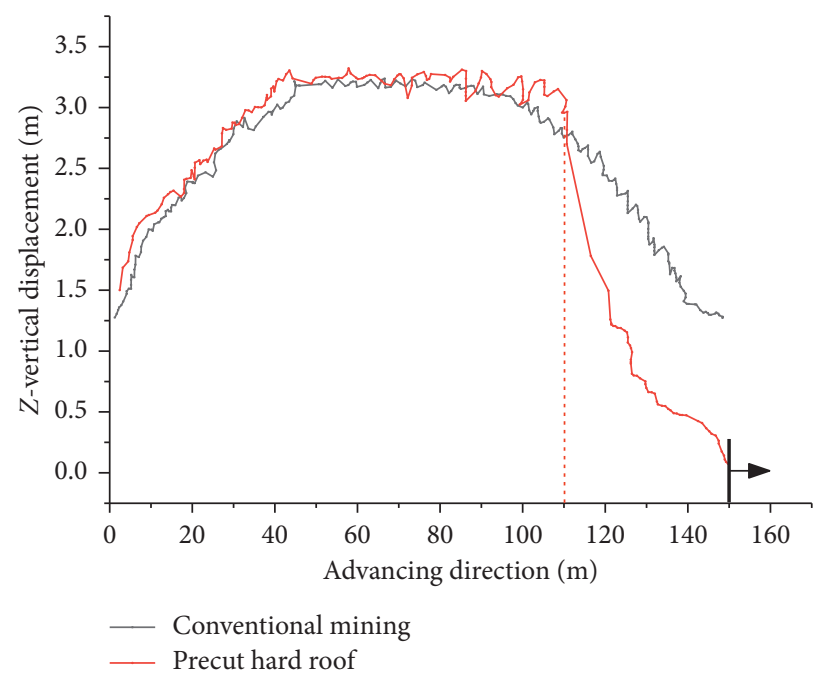

FIgURE 4: Vertical displacement in key strata above gob of panel.

of elastic energy before failure. Based on the pattern of main roof collapse [22], the exposed area of main roof strata in the goaf also increases with the continuous advance of working face. Based on the distribution pattern of rectangular plate bending moment, the middle of the long edge of the plate reaches the ultimate strength of rock layer at first to form a fracture when the exposed area increases to a certain value. Then, the failure position occurs in the middle of the short edge. And the cracks will form around the plate and destroy gradually. The release of bending elastic energy led to produce the stress wave, and the subsidence of the roof will be rapidly transmitted to the 

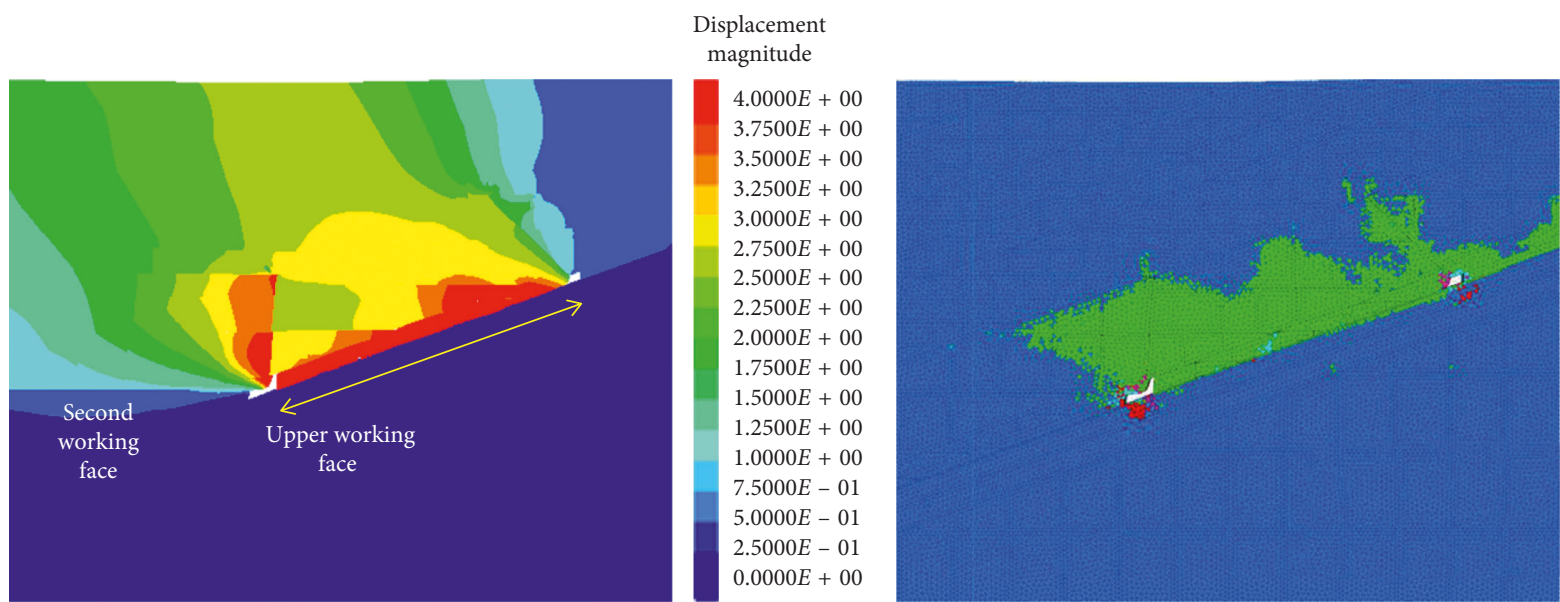

Block

Color by state
- Shear-n shear-p
- Shear-n shear-p tension-p

(b)

Displacement

magnitude

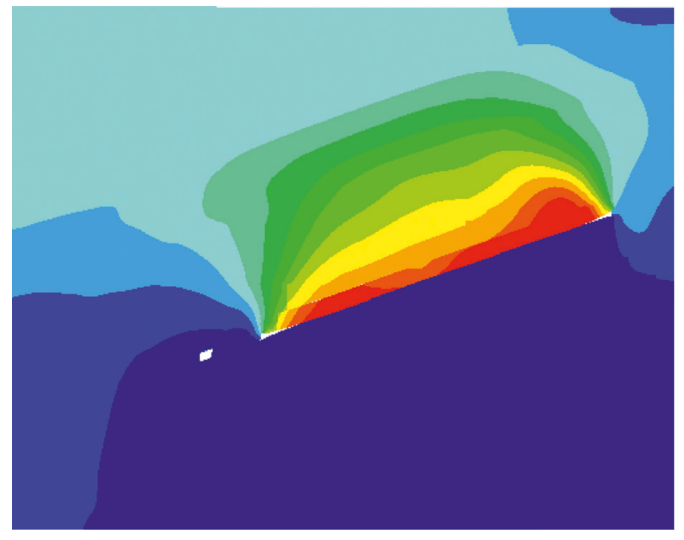

$4.0000 E+00$
$3.7500 E+00$
$3.5000 E+00$
$3.2500 E+00$
$3.0000 E+00$
$2.7500 E+00$
$2.5000 E+00$
$2.2500 E+00$
$2.0000 E+00$
$1.7500 E+00$
$1.5000 E+00$
$1.2500 E+00$
$1.0000 E+00$
$7.5000 E-01$
$5.0000 E-01$
$2.5000 E-01$
$0.0000 E+00$

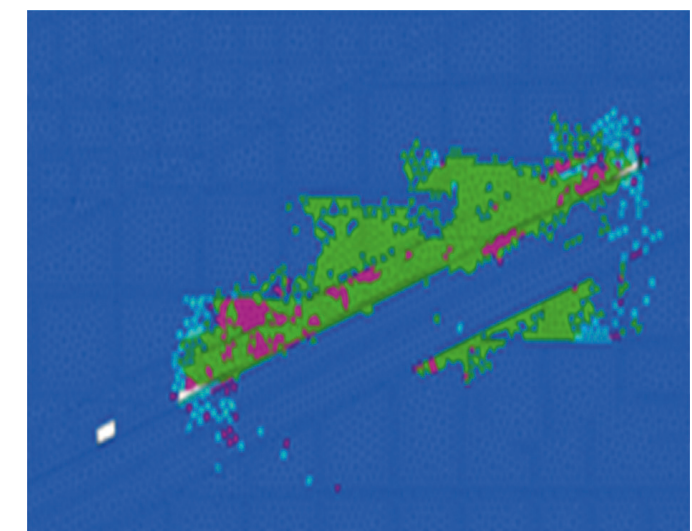

Block

Color by state
- Shear-n shear-p
- Shear-n shear-p tension-p
Shear-p tension-
- Tension-n shear-p tension-p

(d)

FIGURE 5: Vertical displacement and plastic zone in the GERPOHR and conventional mining method. (a) GERPOHR z-displacement. (b) GERPOHR plastic zone distribution. (c) Conventional mining z-displacement. (d) Conventional mining plastic zone distribution.

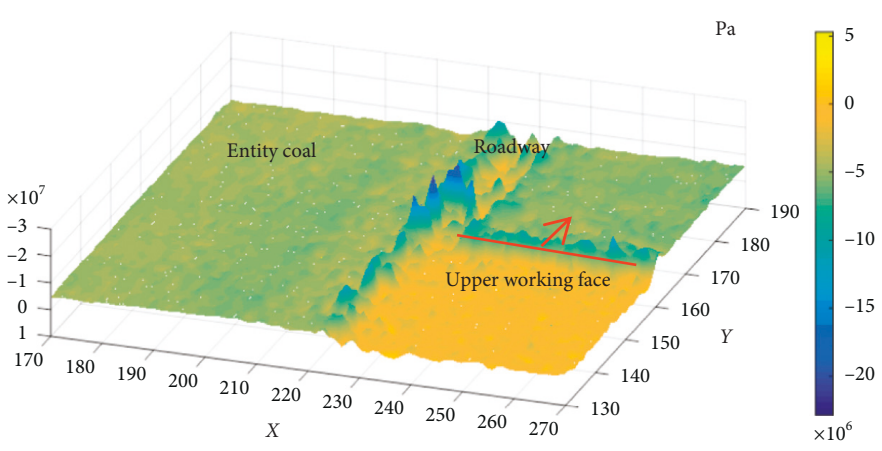

(a)

FIgURe 6: Continued. 


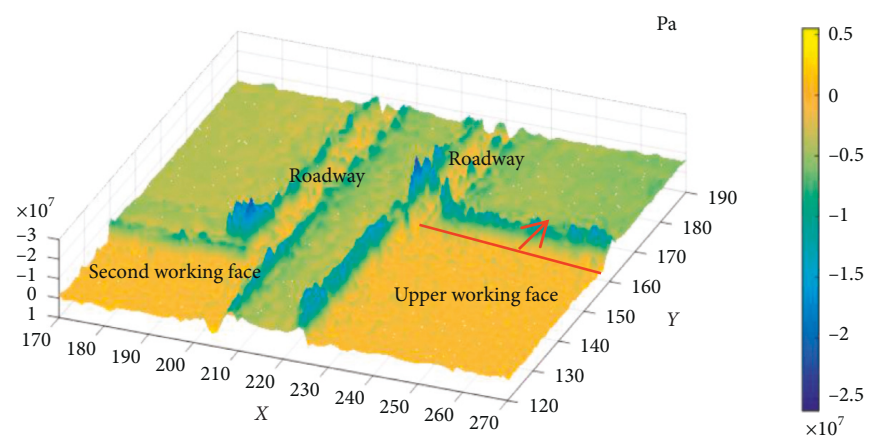

(b)

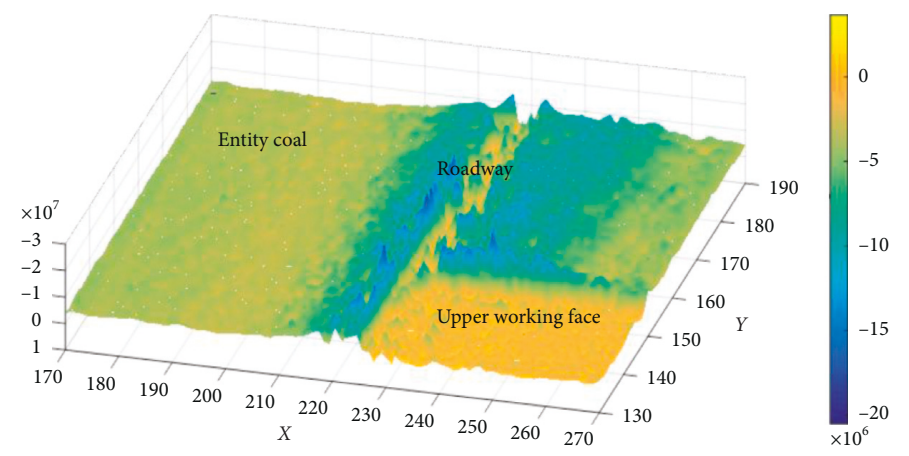

(c)

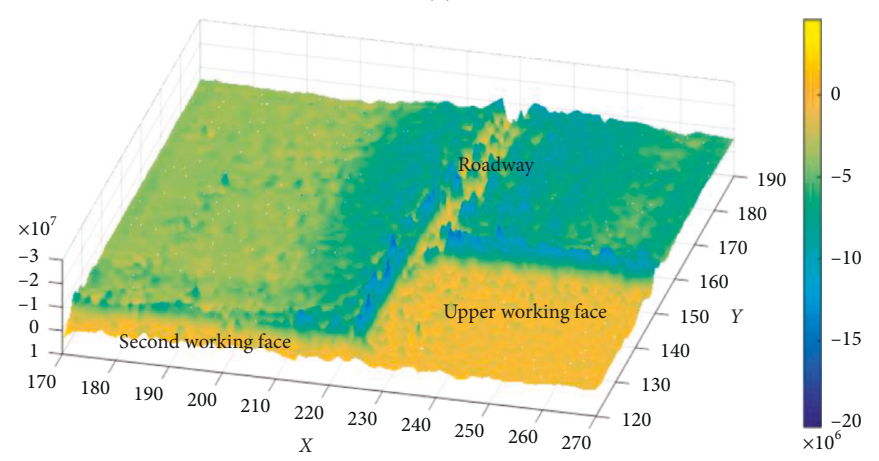

(d)

FIGURE 6: Distribution of vertical abutment pressure under the conventional mining and GERPOHR condition. (a) Conventional mining to excavate upper working face. (b) Conventional mining to excavate second working face. (c) Precut overhanging hard roof mining to excavate upper working face. (d) Precut overhanging hard roof mining to excavate second working face.

roadway. The stress will fluctuate violently in the roadway roof. It may cause rockburst. Compared with conventional mining method, precut overhanging hard roof mining also produces elastic energy release of hard and thick strata. However, due to the effect of presplitting cut, stress wave transmission will greatly decrease. Meanwhile, the lateral influence caused by the subsidence of hard and thick strata will be avoided.

The numerical simulation model can nearly realistically simulate the response of the low and hard thick strata. The detection point was selected for szz analysis (about $1.5 \mathrm{~m}$ from roof and the distance from the initial mining position is $160 \mathrm{~m})$. When the hard and thick strata break, the vertical stress of roadway roof fluctuates from $40 \mathrm{MPa}$ to $25 \mathrm{MPa}$ under conventional mining condition. However, the vertical stress of roadway roof fluctuates more smoothly in the GERPOHR method (Figure 9).

\section{Conclusion}

Based on the mechanism of rockburst under the condition of hard and thick strata, this paper proposed the idea of preventing rockburst by the GERPOHR method. Then, the stress distribution characteristics of conventional mining and precut overhanging hard roof mining were studied by using 3DEC discrete element software. The following conclusions were obtained:

(1) The study shows that the GERPOHR method can reduce stress concentration of coal pillar. The roadway was located in the less stress region. Thus, the possibility of rockburst was reduced.

(2) Numerical simulation result shows that cutting roof could change the boundary conditions of hard and thick rock strata. Therefore, the first weighting 


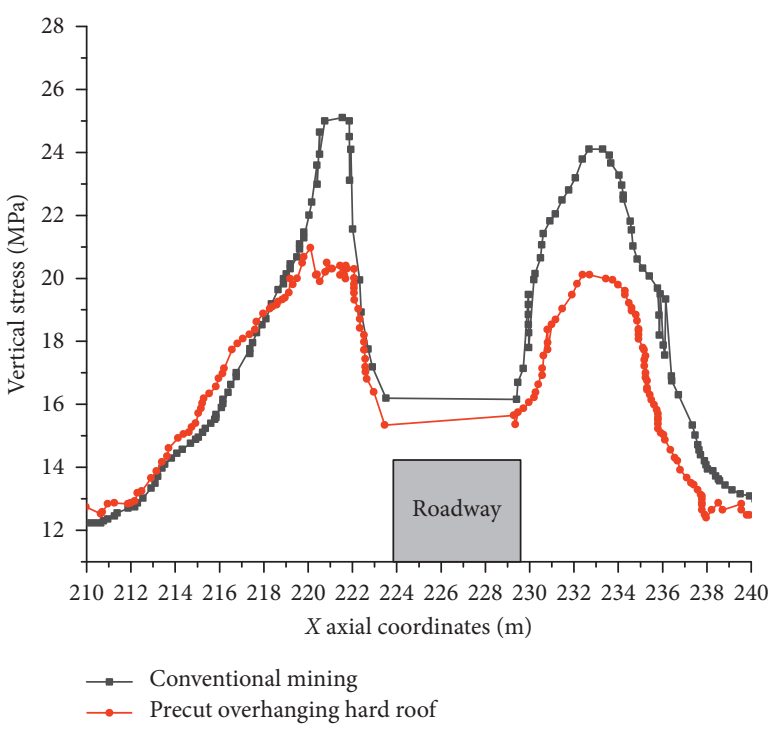

(a)

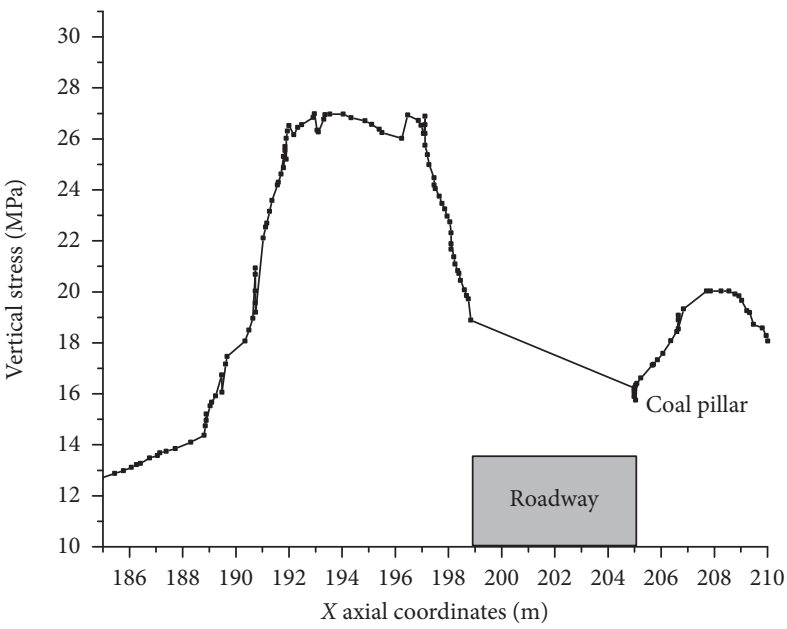

(b)

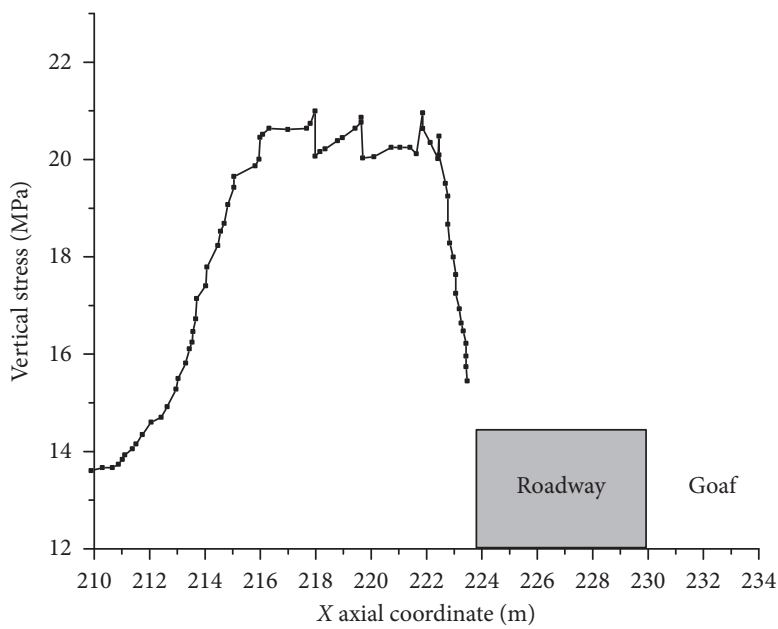

(c)

Figure 7: Distribution of stress around roadway. (a) Excavate upper working face. (b) Excavate second working face by conventional mining. (c) Excavate second working face by precut overhanging hard roof mining.

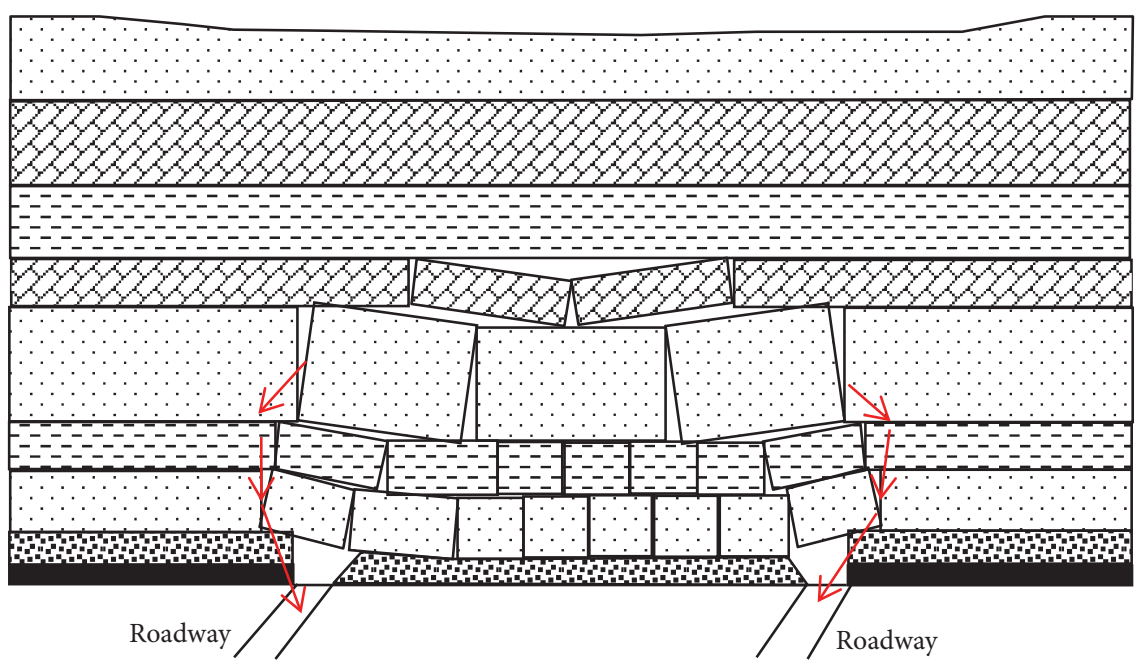

(a)

Figure 8: Continued. 


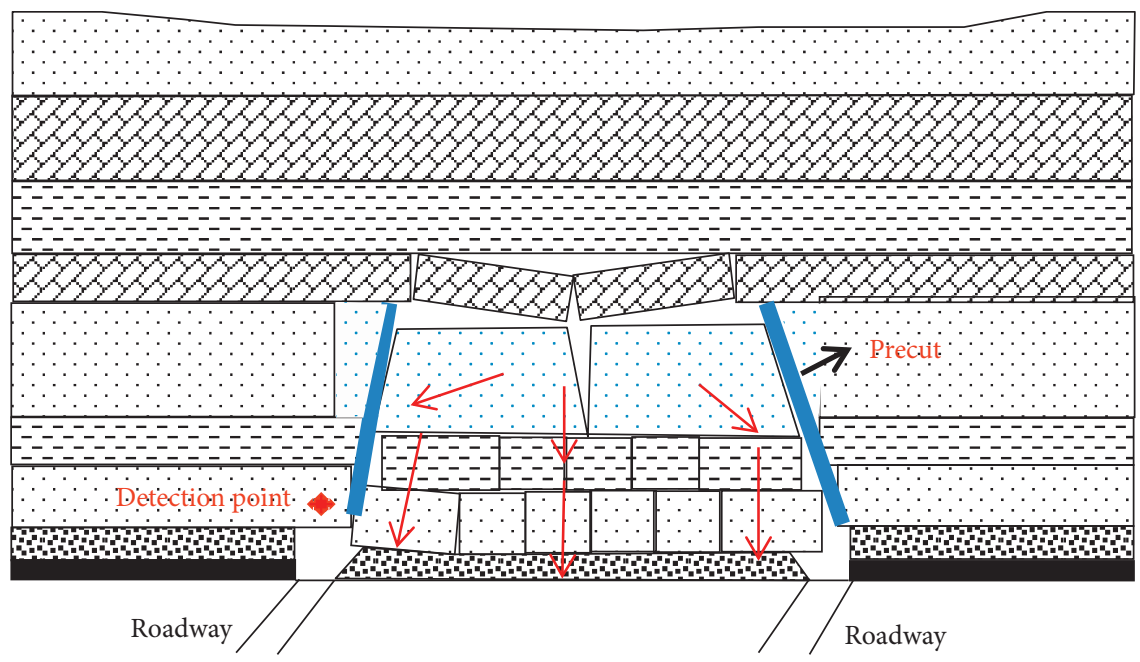

(b)

FIGURE 8: Model illustrating structures formed within overburden and dynamic evolution process of roadway roof stress in the conventional mining method and gob-side entry retaining through precut overhanging hard roof method. (a) The conventional mining method. (b) The gob-side entry retaining through precut overhanging hard roof method.

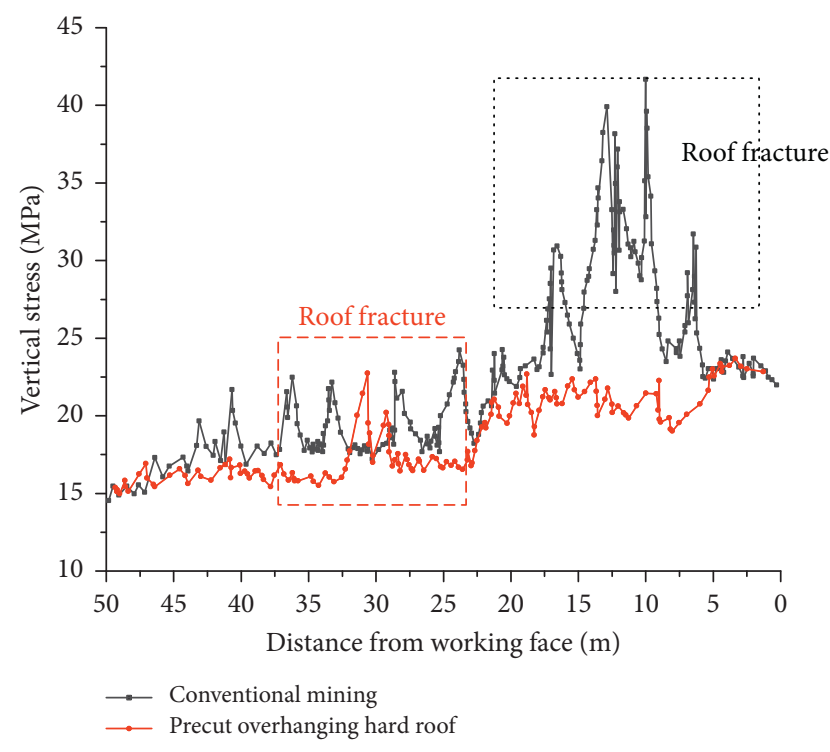

Figure 9: Dynamic evolution process of roadway roof stress.

interval of main roof was reduced. Under the conventional mining condition, the hard and thick strata break when advancing about $140-150 \mathrm{~m}$. Under the roof cutting condition, the initial pressure interval of hard and thick rock strata is about $110-120 \mathrm{~m}$. After the gob-side entry retaining was completed, the surrounding rock of roadway would be in the plastic zone. Thus, the accumulation of energy could be avoided in second working face mining. Due to the influence of rock dip angle, the distribution of plastic zone is asymmetric.

(3) The GERPOHR method can reduce the peak value of abutment pressure. Under the traditional mining condition, the peak value of abutment pressure is about $27 \mathrm{MPa}$. The peak value of abutment pressure is about $21 \mathrm{MPa}$ when the precut overhanging hard roof method is adopted.

(4) Theoretical and numerical analysis results show that this method can restrain the stress perturbation. Under the conventional mining condition, the stress fluctuation range caused by hard and thick rock fracture is $25-40 \mathrm{MPa}$. Stress fluctuation is more smooth under the GERPOHR method.

\section{Data Availability}

The data used to support the findings of this study are available from the corresponding author upon request.

\section{Conflicts of Interest}

The authors declare that they have no conflicts of interest.

\section{Acknowledgments}

This work was supported by the National Key R\&D Program of China (2016YFC0600901), by China National Power Grid Corp Headquarters Science and Technology Project, and also by State Grid Corporation of China.

\section{References}

[1] A. T. Iannacchione and S. C. Tadolini, "Occurrence, predication, and control of coal burst events in the U.S," International Journal of Mining Science and Technology, vol. 26, no. 1, pp. 39-46, 2016.

[2] C. Wei, C. Zhang, I. Canbulat, A. Cao, and L. Dou, "Evaluation of current coal burst control techniques and development of a coal burst management framework," Tunnelling and Underground Space Technology, vol. 81, pp. 129-143, 2018.

[3] C. Zhang, I. Canbulat, B. Hebblewhite, and C. R. Ward, "Assessing coal burst phenomena in mining and insights into 
directions for future research," International Journal of Coal Geology, vol. 179, pp. 28-44, 2017.

[4] T. B. Zhao, W. Y. Guo, F. H. Yu, Y.-L. Tan, B. Huang, and S.-C. Hu, "Numerical investigation of influences of drilling arrangements on the mechanical behavior and energy evolution of coal models," Advances in Civil Engineering, vol. 2018, Article ID 3817397, 12 pages, 2018.

[5] Z. Yang, C. Liu, S. Tang, L. Dou, and J. Cao, "Rock burst mechanism analysis in an advanced segment of gob-side entry under different dip angles of the seam and prevention technology," International Journal of Mining Science and Technology, vol. 28, no. 6, pp. 891-899, 2018.

[6] W. Cai, L. Dou, M. Zhang, W. Cao, J. Shi, and L. Feng, "A fuzzy comprehensive evaluation methodology for rock burst forecasting using microseismic monitoring," Tunnelling and Underground Space Technology, vol. 80, pp. 232-245, 2018.

[7] P. Wang, J. Zhao, Y. P. Chugh, and Z. Wang, "A novel longwall mining layout approach for extraction of deep coal deposits," Minerals, vol. 7, no. 4, p. 60, 2017.

[8] S. Dehghan, K. Shahriar, P. Maarefvand, and K. Goshtasbi, "3-D modeling of rock burst in pillar No.19 of Fetr6 chromite mine," International Journal of Mining Science and Technology, vol. 23, no. 2, pp. 231-236, 2013.

[9] P. Konicek, M. R. Saharan, and H. Mitri, "Destress blasting in coal mining - state-of-the-art review," Procedia Engineering, vol. 26, no. 4, pp. 179-194, 2011.

[10] V. Frid, "Electromagnetic radiation method water-infusion control in rockburst-prone strata," Journal of Applied Geophysics, vol. 43, no. 1, pp. 5-13, 2000.

[11] C. C. Li, "A new energy-absorbing bolt for rock support in high stress rock masses," International Journal of Rock Mechanics and Mining Sciences, vol. 47, no. 3, pp. 396-404, 2010.

[12] H. He, L. Dou, J. Fan, T. Du, and X. Sun, "Deep-hole directional fracturing of thick hard roof for rockburst prevention," Tunnelling and Underground Space Technology Incorporating Trenchless Technology Research, vol. 32, no. 6, pp. 34-43, 2012.

[13] P. Konicek, K. Soucek, L. Stas, and R. Singh, "Long-hole destress blasting for rockburst control during deep underground coal mining," International Journal of Rock Mechanics and Mining Sciences, vol. 61, pp. 141-153, 2013.

[14] Z. Li, L. Dou, G. Wang, W. Cai, J. He, and Y. Ding, "Risk evaluation of rock burst through theory of static and dynamic stresses superposition," Journal of Central South University, vol. 22, no. 2, pp. 676-683, 2015.

[15] M. S. Gao, L. M. Dou, Z. Nong et al., "Cusp catastrophic model for instability of coal pillar burst damage and analysis of its application," Journal of China University of Mining and Technology, vol. 34, no. 4, pp. 433-437, 2005.

[16] H. E. Manchao, S. Chen, Z. Guo et al., "Control of surrounding rock structure for gob-side entry retaining by cutting roof to release pressure and its engineering application," Journal of China University of Mining and Technology, vol. 46, no. 5, pp. 959-969, 2017.

[17] M. C. He, G. L. Zhu, and Z. B. Guo, "Longwall mining "cutting cantilever beam theory" and 110 mining method in China-the third mining science innovation," Journal of Rock Mechanics and Geotechnical Engineering, vol. 7, no. 5, pp. 483-492, 2015.

[18] Y. Wang, Y. Gao, E. Wang, M. He, and J. Yang, "Roof deformation characteristics and preventive techniques using a novel non-pillar mining method of gob-side entry retaining by roof cutting," Energies, vol. 11, no. 3, p. 627, 2018.
[19] G. F. Zhang, H. E. Man-Chao, Y. U. Xue-Ping et al., "Research on the technique of No-pillar mining with gob-side entry formed by advanced roof caving in the protective seam in baijiao coal mine," Journal of Mining and Safety Engineering, vol. 28, no. 4, pp. 511-516, 2011.

[20] X. Sun, X. Liu, G. Liang et al., "Key parameters of gob-side entry retaining formed by roof cut and pressure releasing in thin coal seams," Chinese Journal of Rock Mechanics and Engineering, vol. 33, no. 7, pp. 1449-1456, 2014.

[21] P. A. Cundall, NESSI-Soil Structure Interaction Program for Dynamic and Static Problems, Report 51508-9, Norwegian Geotechnical Institute, Norway, 1980.

[22] J. Xu, "Study of features of distribution of overlaying stratum fractures caused by mining," Ground Pressure and Strata Control, vol. 3, no. 4, pp. 210-212, 1997. 


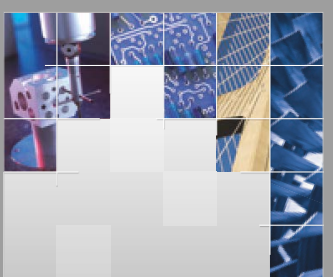

\section{Enfincering}
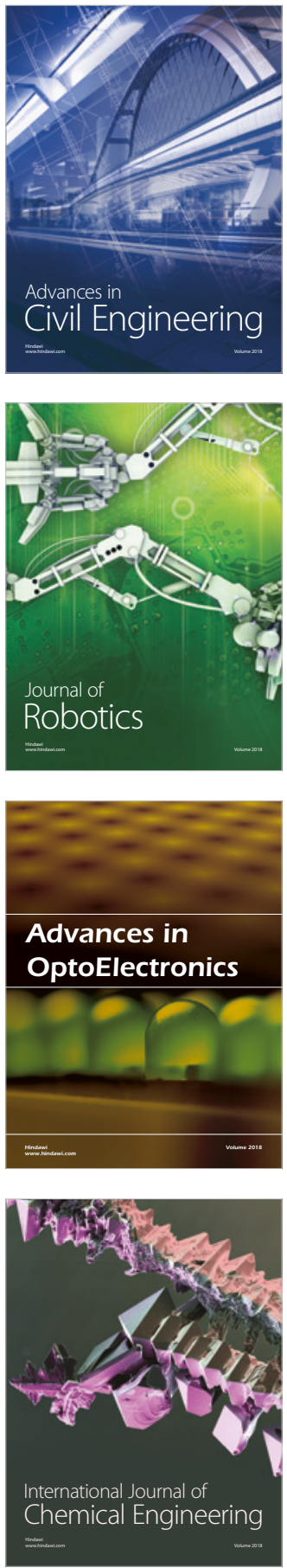

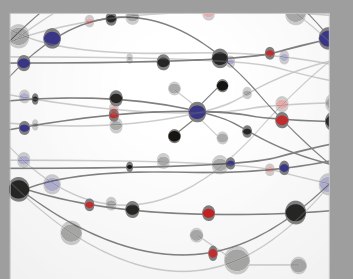

\section{Rotating \\ Machinery}

The Scientific World Journal

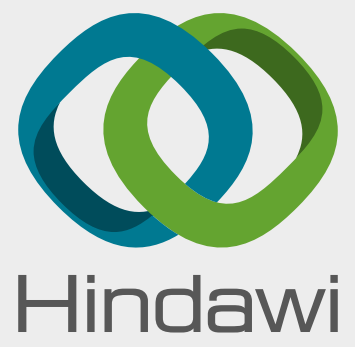

Submit your manuscripts at

www.hindawi.com
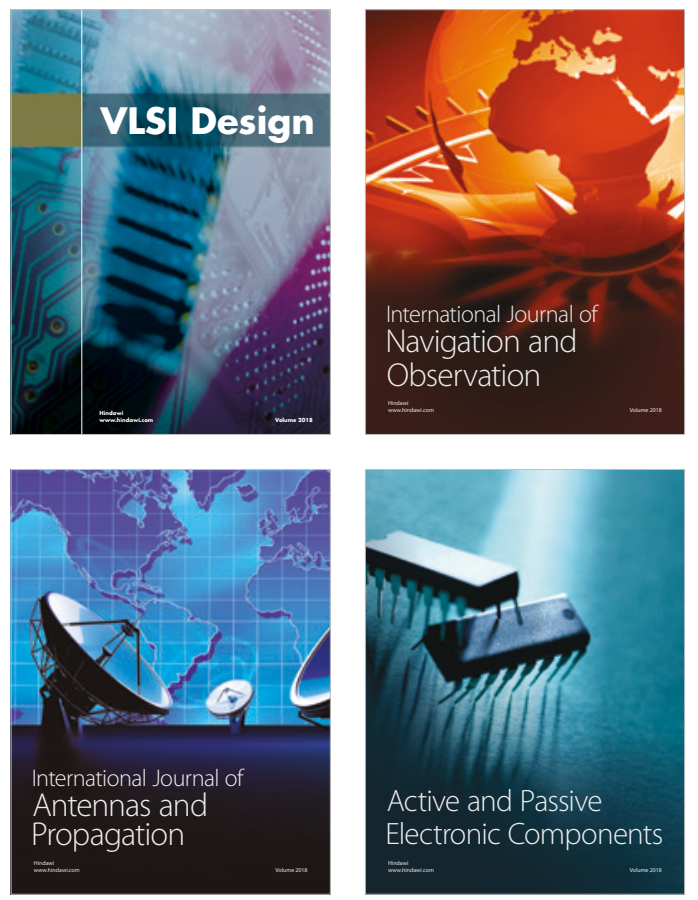
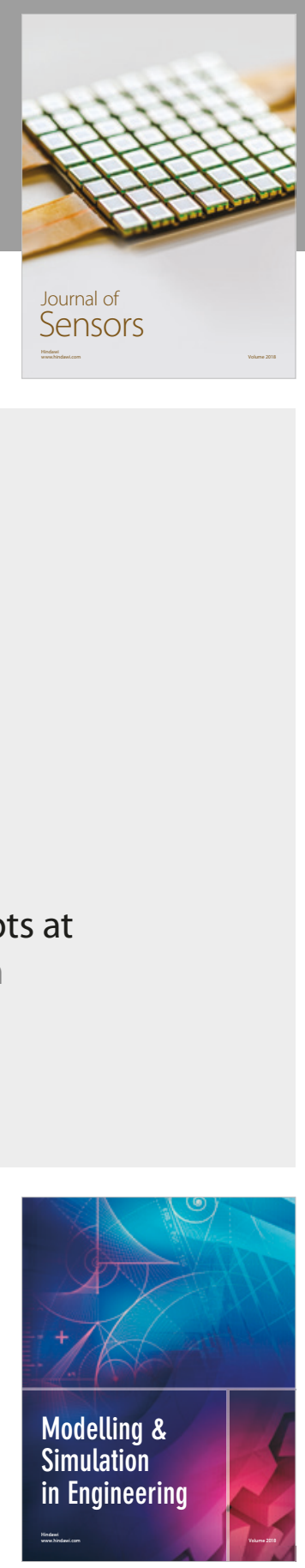

\section{Advances \\ Multimedia}
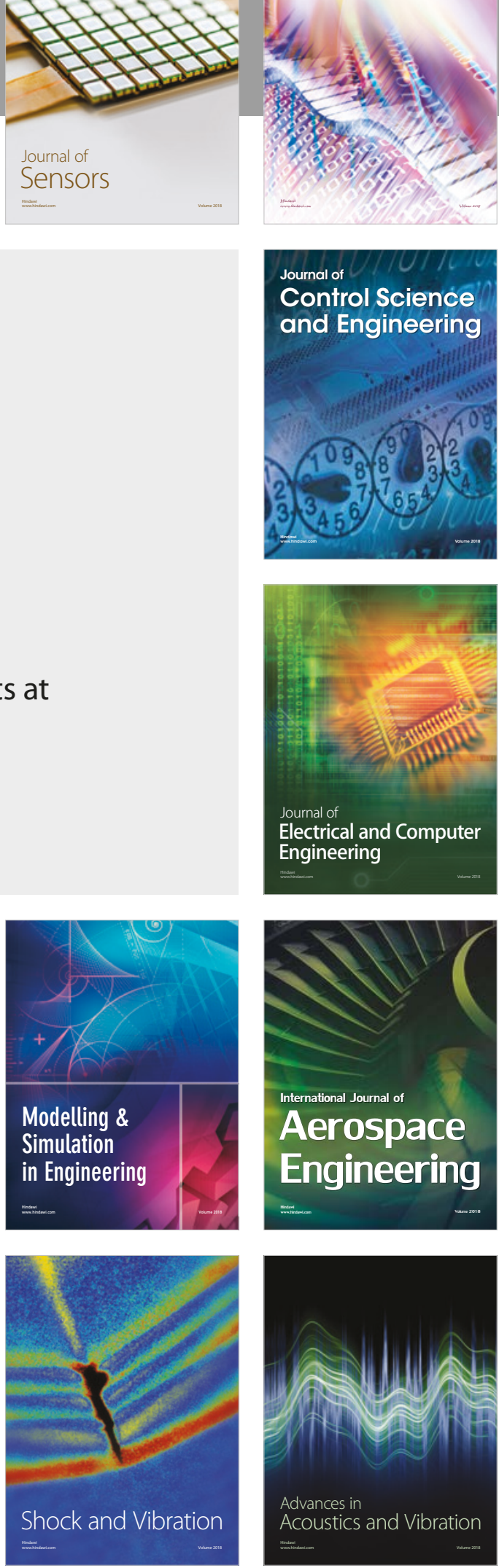